\title{
Peran Core Self-Evaluation dan Dukungan Atasan terhadap Pengayaan Kerja Keluarga
}

\author{
Maudy Safira Ervinadi, Artiawati, Darmawan Muttaqin \\ Fakultas Psikologi, Universitas Surabaya, Indonesia \\ e-mail: darmawan.muttaqin@staff.ubaya.ac.id
}

\begin{abstract}
In recent years, the number of women workers has increased, it means women participate in both work and family roles together. Interaction between work family life can also provide benefits in improving the quality of work-family life if managed properly. Core self-evaluation and supervisor support are the factors that cannot be separated from work-family life. The purpose of this study is to examine the role of core self-evaluation and supervisor support in predicting work-family enrichment using quantitative research method and collecting data through questionnaire. Measurements used in this study were Work-Family Enrichment Scale, Core Self-Evaluation Scale, and Supervisor Support Subscale from the Social Support Scale include supervisor emotional and instrumental support. Data were collected from 113 employees aged 20-59 with at least one child. The result indicates that core self-evaluation and supervisor support are the predictors of work-family enrichment. However, instrumental support from supervisor is not a predictor of work-family enrichment. Work-family enrichment happens when the individual has a positive core self-evaluation and sensing that the individual got support from supervisor.
\end{abstract}

Keywords: core self-evaluation, supervisor support, work family enrichment

\begin{abstract}
Abstrak
Pada beberapa tahun terakhir kehadiran pekerja perempuan mengalami peningkatan, hal ini menandakan bahwa perempuan berpartisipasi dalam peran pekerjaan dan keluarga secara bersamaan. Interaksi antara kehidupan kerja dan keluarga dapat memberikan manfaat dalam peningkatan kualitas kehidupan kerja keluarga apabila dikelola dengan baik. Penilaian diri dan dukungan atasan menjadi faktor yang tidak dapat dipisahkan dalam kehidupan kerja dan keluarga. Penelitian ini bertujuan untuk menguji peran core self-evaluation dan dukungan atasan dalam memprediksi pengayaan kerja keluarga. Penelitian menggunakan metode kuantitatif dan pengumpulan data melalui kuesioner. Alat ukur yang digunakan yaitu Work Family Enrichment Scale, Core Self-Evaluation Scale dan subskala dukungan atasan dari Social Support Scale yang mencakup dukungan instrumental dan emosional. Penelitian ini melibatkan 113 karyawan yang berusia 20-59 tahun yang telah bekerja dan memiliki minimal satu orang anak. Hasil penelitian menunjukkan bahwa core self-evaluation dan dukungan emosional dari atasan dapat memprediksi pengayaan kerja keluarga. Namun, dukungan instrumental tidak memprediksi pengayaan kerja keluarga.
\end{abstract}

Kata Kunci: core self-evaluation, dukungan atasan, pengayaan kerja keluarga

\section{Pendahuluan}

Kehadiran pekerja perempuan saat ini bukanlah merupakan hal yang asing, mengingat bahwa saat ini kehadiran pekerja perempuan mengalami peningkatan dibandingkan sebelumnya. Data Badan Pusat Statistik (BPS) menyebutkan jumlah pekerja perempuan per Februari 2016 mencapai $52.71 \%$ dan per Februari 2017 jumlah pekerja perempuan meningkat sebanyak $2.33 \%$ menjadi $55.04 \%$ (Jawa Pos, 2017). Hal ini menandakan bahwa perempuan saat ini semakin terlibat dalams dunia pekerjaan. Melihat hal tersebut maka 
banyaknya jumlah pasangan suami istri yang bekerja menjadikan topik kehidupan kerja dan keluarga menarik untuk diteliti. Penelitian mengenai kehidupan kerja dan keluarga masih berfokus pada sisi negatif dari interaksi antara domain pekerjaan dan keluarga atau sering disebut dengan konflik kerja keluarga, selain itu juga memperhatikan dampak negatif dari interaksi kerja keluarga seperti ketidakpuasan dalam bekerja atau stres kerja. Beberapa peneliti mencoba mengkaji interaksi antara kerja dan keluarga dalam sisi positif, seperti McNall (2010) yang mencoba untuk mengeksplorasi kemungkinan adanya sisi positif dari kehidupan kerja dan keluarga. Temuan dari McNall (2010) menunjukkan bahwa menjalani kedua peran pada domain pekerjaan dan keluarga dapat memberikan kepuasan kerja, kepuasan keluarga maupun kepuasaan hidup, meningkatkan komitmen afektif, mengurangi turnover dan meningkatkan kesehatan mental. Hal ini mengindikasikan bahwa kehidupan kerja dan keluarga tidak selalu bersifat negatif tetapi dapat memberikan pengaruh positif apabila dikelola dengan baik (Astutik \& Artiawati, 2017).

Salah satu konsep mengenai sisi positif dari kehidupan kerja dan keluarga yaitu pengayaan kerja keluarga (Greenhaus \& Powell, 2006). Pengayaan kerja keluarga didefinisikan sebagai pengalaman dalam satu peran dapat meningkatkan kualitas hidup pada peran yang lain (Greenhaus \& Powell, 2006). Pengayaan kerja keluarga dapat terjadi secara bidirectional yaitu dari domain kerja ke domain keluarga dan sebaliknya. Pengayaan kerja terhadap keluarga atau disebut work family enrichment mengarah pada pengalaman di tempat kerja dapat memperbaiki kehidupan keluarga, sedangkan pengayaan keluarga terhadap kerja atau yang disebut family work enrichment mengarah pada kehidupan dalam keluarga memengaruhi secara positif terhadap pekerjaan (Hennessy, 2007).
Secara lebih lanjut, Carlson dkk. (2006) memperinci pengayaan kerja terhadap keluarga yang terdiri work family affect yang didefinisikan sebagai keterlibatan pada hasil kerja dalam keadaan atau sikap emosi positif yang mengarahkan individu menjadi anggota dalam keluarga untuk lebih baik, contohnya ketika berada pada pekerjaan, seorang individu mendapatkan pujian dari atasannya maka individu akan merasakan emosi positif dan membantunya menjadi anggota keluarga yang lebih baik. Work family development dijelaskan sebagai keterlibatan pada pekerjaan mengarah pada perolehan atau penyempurnaan keterampilan, pengetahuan, perilaku, atau cara melihat hal-hal yang mengarahkan individu menjadi anggota keluarga yang lebih baik, misalnya ketika di kantor karyawan menerima pelatihan mengenai time management yang akhirnya membantu mereka untuk mengelola waktu ketika berada di rumah. Work family capital dijelaskan sebagai keterlibatan dalam pekerjaan yang dapat mempromosikan tingkat sumber daya psikososial seperti rasa aman, kepercayaan diri, pencapaian, atau pemenuhan diri yang mengarahkan individu menjadi anggota keluarga yang lebih baik, misalnya dengan mendapatkan bonus dari perusahaan yang dapat membantu individu untuk dapat memenuhi kebutuhan diri sehingga menjadi anggota keluarga yang lebih baik.

Sebaliknya dengan pengayaan keluarga terhadap kerja dapat berupa family work affect yang didefinisikan sebagai keterlibatan pada keluarga dalam keadaan emosi positif atau sikap positif yang mengarahkan individu menjadi pekerja yang lebih baik, misalnya individu mendapatkan semangat dari keluarga untuk bekerja, maka dapat meningkatkan performa dirinya ketika berada dalam pekerjaan untuk menjadi pekerja yang lebih baik. Family work development didefinisikan sebagai keterlibatan dalam keluarga yang mengarahkan individu untuk memperoleh sesuatu yang dapat 
membuatnya menjadi seorang pekerja yang lebih baik, misalnya individu mendapatkan masukan atau saran dari anggota keluarga ketika mengalami permasalahan dalam pekerjaan, maka hal tersebut membantu individu untuk menjadi pekerja yang lebih baik. Family work efficiency juga didefinisikan sebagai keterlibatan dengan keluarga mampu memberikan rasa fokus yang dapat membantu individu untuk menjadi pekerja yang lebih baik, misalnya sebagai anggota keluarga individu dapat terlibat langsung dengan keluarganya, seperti mengurus anak yang ketika individu terlibat langsung, maka dalam pekerjaan hal itu dapat membantunya menjadi pekerja yang lebih baik karena tidak memikirkan anak di rumah.

Pengayaan kerja keluarga dapat terjadi melalui jalur instrumental dan afektif (Greenhaus \& Powell, 2006). Jalur instrumental terjadi ketika sumber daya yang didapatkan pada salah satu peran secara langsung meningkatkan kinerja yang lebih tinggi pada peran yang lain, contohnya ketika individu berada di kantor dapat mempelajari cara mengelola konflik yang ketika digunakan dalam keluarga dapat menyelesaikan konflik secara lebih efektif baik dengan anak ataupun pasangannya (Carlson dkk., 2006). Berbeda dengan jalur instrumental tersebut, jalur afektif terjadi ketika sumber daya yang diperoleh pada salah satu peran menghasilkan emosi positif, yang secara tidak langsung dapat meningkatkan kinerja pada peran yang lain, contohnya seorang individu yang meninggalkan pekerjaan dalam suasana hati yang positif, cenderung merespon secara lebih positif, sabar, dan bahagia untuk anggota keluarganya, yang pada akhirnya dapat meningkatkan pengaruh dan kinerjanya sebagai orang tua atau pasangan (Carlson dkk., 2006).

Terciptanya pengayaan kerja keluarga memberikan manfaat bagi individu yang menjalani kehidupan kerja dan keluarga. Pada domain pekerjaan, adanya pengayaan kerja keluarga dapat memprediksi meningkatnya kepuasan kerja, komitmen organisasi, keterlibatan kerja, dan menurunkan intensitas turnover (Akram dkk., 2014; Carlson dkk., 2009; Jaga \& Bagraim, 2011; Koekemoer dkk., 2017; Marais dkk., 2014; Siu dkk., 2015). Sebaliknya pada domain keluarga, individu yang mengalami pengayaan kerja keluarga akan lebih dapat menunjukkan keterlibatan keluarga dan merasakan kepuasan keluarga (Hunter dkk., 2010; Jaga \& Bagraim, 2011; Marais dkk., 2014; Siu dkk., 2015). Tidak hanya berdampak pada domain pekerjaan dan keluarga, pengayaan kerja keluarga juga memberikan manfaat bagi domain personal, berupa kesehatan mental dan kepuasan hidup (McNall dkk., 2010).

Terjadinya pengayaan kerja keluarga dapat dipahami dengan menggunakan kerangka sumber daya dan tuntutan (Voydanoff, 2004). Kerangka sumber daya dan tuntutan menjelaskan bahwa pengalaman kerja yang berpengaruh terhadap kehidupan keluarga, tergantung pada penilaian kognitif individu mengenai sumber daya yang tersedia untuk memenuhi tuntutan peran. Secara lebih lanjut, Voydanoff (2005) mendefinisikan sumber daya sebagai aset struktural atau psikologis yang dapat digunakan untuk memfasilitasi kinerja, mengurangi tuntutan, dan bahkan menghasilkan sumber daya tambahan. Sumber daya tersebut dapat berupa sumber daya psikologis seperti kepercayaan diri, energi, waktu, dukungan sosial, sumber daya instrumental atau struktural (seperti kebijakan organisasi) (Baral \& Bhargava, 2011).

Adanya sumber daya yang dimiliki oleh individu tidak selalu menghasilkan pengayaan kerja keluarga. Hal ini bergantung pada faktor individu dalam mengevaluasi diri sendiri atau core selfevaluation (Boyar \& Mosley, 2007). Judge dkk. (2005) menjelaskan bahwa core selfevaluation merupakan penilaian mendasar individu terhadap diri sendiri mengenai kelayakan, kompetensi, dan kemampuan. 
Apabila individu memiliki penilaian yang positif terhadap dirinya maka individu akan mampu mengatasi berbagai situasi baik dalam domain kerja maupun keluarga. Baral dan Bharagava (2011) menjelaskan bahwa individu yang memiliki core selfevaluation memiliki motivasi untuk memaksimalkan dan memanfaatkan sumber daya yang tersedia dalam menjalankan berbagai peran. Dengan demikian, individu akan mengembangkan keterampilan baru, suasana hati yang positif, kepercayaan diri yang tinggi, dan mendapatkan lebih banyak keuntungan yang dapat digunakan untuk menjalani tanggung jawab pada peran yang lain.

Beberapa penelitian sebelumnya yang berkaitan dengan peran sumber daya yang dimiliki individu terhadap pengayaan kerja keluarga, menemukan bahwa dukungan sosial yang diterima dapat meningkatkan kualitas kehidupan baik pada domain kerja maupun keluarga (Greenhaus \& Powell, 2006; Shein \& Chen, 2011). Dukungan sosial dapat diberikan oleh orang lain yang berada pada domain keluarga (Siu dkk., 2015). Tidak hanya berasal dari domain keluarga, dukungan sosial juga didapatkan pada domain pekerjaan melalui rekan kerja dan atasan (Beham dkk., 2011; Molino dkk., 2013). Dukungan atasan dapat membantu karyawan dalam menjembatani batas antara pekerjaan dan keluarga ketika karyawan berusaha mengintegrasikan pekerjaan dan tanggung jawab keluarga (Winfield \& Rushing, 2005).

Dukungan yang diberikan oleh atasan dapat berupa dukungan emosional seperti mengekspresikan kepedulian dan empati terhadap karyawan ketika menghadapi tantangan dalam mengelola tanggung jawab pekerjaan dan keluarga. Selain dukungan emosional, dukungan instrumental juga dapat diberikan atasan dengan memberikan fleksibilitas dalam menjadwalkan jam kerja karyawan dan memberikan izin untuk karyawan tidak masuk kerja ketika sedang ada tanggung jawab keluarga yang mendadak (Baral \& Bhargava, 2011).
Tersedianya dukungan yang diberikan atasan kepada karyawan menunjukkan adanya kepedulian organisasi terhadap kesejahteraan individu dan memberikan bantuan untuk memastikan efektivitas karyawan dalam bekerja (Kossek dkk., 2011). Dukungan atasan dapat mengurangi kecenderungan untuk mengundurkan diri dan bahkan dapat memicu karyawan untuk terlibat penuh dalam pekerjaan. Adanya dukungan dari atasan dapat menciptakan situasi kerja yang kondusif sehingga karyawan merasa lebih nyaman untuk mendiskusikan tantangan pekerjaan dan keluarga dengan atasannya (Kossek dkk., 2011). Selain itu, dukungan yang diterima dari atasan yang berupa sumber daya dapat dikembangkan untuk meningkatkan kualitas dalam menjalani peran pada domain keluarga. Hal ini disebabkan dukungan atasan dapat memperluas sumber daya psikologis individu, berupa kepercayaan diri dalam menangani pekerjaan dan kewajiban pada peran keluarga secara efektif, tanpa menimbulkan dampak negatif dari pertumbuhan karier pada pekerjaan (Baral \& Bhargava, 2011).

Berdasarkan penjelasan di atas, penelitian ini mencoba untuk menguji peran core self-evaluation dan dukungan atasan terhadap pengayaan kerja keluarga. Tidak hanya menguji peran core selfevaluation dan dukungan atasan terhadap pengayaan kerja keluarga secara umum tetapi juga penelitian ini akan menguji peran core self-evaluation dan dukungan atasan terhadap arah dan dimensi dari pengayaan kerja keluarga. Hipotesis yang digunakan dalam penelitian ini adalah terdapat peran core self-evaluation dan dukungan atasan dalam memprediksi pengayaan kerja keluarga (arah dan dimensi).

Penelitian ini mengacu pada positive psychology dalam konteks organisasi sehingga diharapkan dapat memberikan dampak positif berupa menciptakan peningkatan kualitas dalam menjalankan peran keluarga dan pekerjaan secara 
bersamaan, sehingga dapat memberikan keuntungan bagi peran keluarga dan peran pekerjaannya. Ketika individu merasa mengalami kesulitan dalam mengelola pekerjaan dan keluarganya maka atasan yang dinilai sebagai agen organisasi, dapat memberikan bantuan dalam bentuk dukungan-dukungan yang tepat.

\section{Metode Penelitian}

Metode penelitian yang digunakan adalah metode kuantitatif dengan pengumpulan data menggunakan kuesioner. Partisipan merupakan 113 karyawan yang bekerja di suatu perusahaan di Madiun yang terdiri dari 72 karyawan laki-laki $(63.73 \%)$ dan 41 karyawan perempuan (36.27\%) dengan rentang usia 20-59 tahun $(\mathrm{M}=33.32, \mathrm{SD}=8.908)$. Partisipan adalah karyawan yang memiliki jabatan sebagai staf yang telah bekerja antara 1-35 tahun $(\mathrm{M}=8.765, \mathrm{SD}=8.079)$. Partisipan memiliki usia pernikahan mulai dari 1 hingga 35 tahun $(\mathrm{M}=8.041, \mathrm{SD}=7.228)$ yang memiliki 1-3 anak $(\mathrm{M}=1.570, \mathrm{SD}=$ $.705)$.

Core Self-Evaluation Scale (CSES) Judge dkk. (2003) yang terdiri 12 item digunakan untuk mengukur penilaian diri terhadap kelayakan, kemampuan, dan kompetensi individu (misalnya "Saya yakin saya akan mengalami kesuksesan dalam hidup"). CSES menggunakan lima pilihan respon mulai dari 1 (sangat tidak sesuai) hingga 5 (sangat sesuai). Pada penelitian ini, CSES memiliki koefisien reliabilitas sebesar .816. Alat ukur core self evaluation dilakukan uji validitas dengan content validity menggunakan metode professional judgement guna mengetahui kesesuaian butir pada variabel yang akan diukur dengan menerjemahkan skala bahasa Inggris ke dalam bahasa Indonesia.

Subskala dukungan atasan dari Social Support Scale (SSS) versi bahasa Indonesia (Antani \& Ayman, 2003; Artiawati, 2012) digunakan untuk mengukur dukungan yang diberikan oleh atasan yang terdiri dari 5 item. Subskala dukungan atasan memiliki dua dimensi yaitu dukungan emosional (2 item, misalnya: "Mendengarkan dan mendiskusikan masalah kesejahteraan saya") dan dukungan instrumental (3 item, misalnya: "Bantuan langsung ketika mendapatkan kesulitan"). Subskala dukungan atasan menggunakan lima pilihan respon mulai dari 1 (sangat tidak sesuai) hingga 5 (sangat sesuai). Koefisien reliabilitas subskala dukungan atasan pada penelitian ini sebesar .893. Alat ukur ini diadaptasi oleh Antani dan Ayman (2003) dan ditambahkan 1 butir oleh project 3535 (Artiawati, 2012).

Work Family Enrichment Scale (WFES) atau skala pengayaan kerja keluarga (Carlson dkk., 2006) digunakan untuk mengukur pengayaan kerja keluarga $(W-F E)$ dan pengayaan keluarga kerja $(F-$ $W E)$ yang terdiri dari 18 item. Skala pengayaan kerja keluarga memiliki enam dimensi dengan 3 item pada setiap dimensi, yang meliputi: work-family development (w-f development) (contoh item: "Keterlibatan saya dalam pekerjaan membantu saya memahami perbedaan sudut pandang dan hal ini membantu saya menjadi anggota keluarga yang lebih baik"); work-family affect (w-f affect) (contoh item: "Keterlibatan saya dalam pekerjaan saya membuat saya memiliki suasana hati yang baik dan hal ini membantu saya menjadi anggota keluarga yang lebih baik"); work-family capital (w-f capital) (contoh item: "Keterlibatan saya dalam pekerjaan saya membantu saya merasa bangga terhadap diri sendiri dan hal ini membantu saya menjadi anggota keluarga yang lebih baik"); family-work development ( $f-w$ development) (contoh item: "Keterlibatan saya dalam keluarga saya, membantu saya mendapatkan pengetahuan dan hal ini membantu saya menjadi pekerja yang lebih baik"); familywork affect ( $f$-w affect) (contoh item: "Keterlibatan saya dalam keluarga saya membuat saya memiliki suasana hati yang baik dan hal ini membantu saya menjadi 
pekerja yang lebih baik"); dan family-work efficiency ( $f-w$ efficiency) (contoh item: "Keterlibatan saya dalam keluarga saya membantu saya dapat mengatur waktu dalam bekerja dan hal ini membantu saya menjadi pekerja yang lebih baik"). Skala ini menggunakan enam pilihan respon mulai dari 1 (sangat tidak sesuai) sampai dengan 6 (sangat sesuai). Koefisien reliabilitas skala ini sebesar .944. Alat ukur pengayaan kerja keluarga mengacu pada Work Family Enrichment Scale oleh Carlson dkk. (2006) yang kemudian diadaptasi oleh Artiawati dan Andhini (2016) sehingga tidak dilakukan uji validitas karena alat ukur yang digunakan sudah dianggap valid.

\section{Hasil Penelitian dan Pembahasan}

Analisis korelasi pada tabel 1 menunjukkan bahwa core self evaluation, dukungan emosional, dan instrumental dari atasan berhubungan dengan pengayaan kerja keluarga. Secara spesifik, core selfevaluation memiliki hubungan positif dengan pengayaan kerja keluarga. Dukungan emosional maupun dukungan instrumental berhubungan positif dengan pengayaan kerja keluarga.

Secara spesifik (tabel 2), core selfevaluation memiliki hubungan positif dengan keenam dimensi pengayaan kerja keluarga. Dukungan emosional berhubungan positif dengan $w-f$ development, $w-f$ affect, $w$ - $f$ capital, dan $f$-w development tetapi tidak berhubungan dengan $f$-w affect, dan $f$-w efficiency. Dukungan instrumental memiliki hubungan positif dengan keenam dimensi pengayaan kerja keluarga.

Hasil analisis regresi pada tabel 3 menunjukkan bahwa core self-evaluation dapat memprediksi pengayaan kerja keluarga, $w-f$ enrichment, dan $f$-w enrichment. Dukungan emosional hanya dapat memprediksi $w-f$ enrichment, sedangkan dukungan instrumental tidak dapat memprediksi pengayaan kerja keluarga, $w$-f enrichment, dan $f$-w enrichment.
Secara spesifik pada tabel 4 , core selfevaluation dapat memprediksi keenam dimensi pengayaan kerja keluarga, sedangkan dukungan emosional dapat memprediksi 3 dimensi yaitu $w-f$ development, $w-f$ affect, dan $w-f$ capital. Berbeda dengan dukungan instrumental yang tidak dapat memprediksi satu pun dimensi pengayaan kerja keluarga.

Hasil penelitian ini menemukan bahwa core self-evaluation dan dukungan atasan dapat berperan sebagai prediktor dari pengayaan kerja keluarga. Hal ini sesuai dengan kerangka sumber daya dan tuntutan (Voydanoff, 2004) yang menyebutkan sumber daya yang salah satunya berupa dukungan atasan dapat menyebabkan terjadinya pengayaan kerja keluarga. Sumber daya yang dimiliki oleh individu tidak selalu menghasilkan pengayaan kerja keluarga. Hal ini bergantung pada faktor individu dalam mengevaluasi diri sendiri atau core self-evaluation (Boyar \& Mosley, 2007).

Secara spesifik, dukungan instrumental dari atasan tidak berperan dalam memprediksi pengayaan kerja keluarga. Secara lebih detail, temuan penelitian ini menunjukkan bahwa core self-evaluation dan dukungan emosional dari atasan dapat memprediksi munculnya pengayaan dari domain pekerjaan ke domain keluarga baik secara development, affect, dan capital. Sebaliknya, pengayaan dari domain keluarga ke domain pekerjaan hanya dapat diprediksi oleh core self-evaluation.

Terbuktinya peran core self-evaluation dapat memprediksi pengayaan kerja keluarga mengindikasikan bahwa penilaian positif terhadap kelayakan, kemampuan, dan kompetensi individu dapat memengaruhi penilaian terhadap suatu situasi baik dalam situasi domain pekerjaan maupun keluarga (Judge dkk., 2004; McNall dkk., 2010). 
Tabel 1

Hubungan Variabel Independen dengan Pengayaan Kerja Keluarga

\begin{tabular}{lccc}
\hline & Total W-FE & W-FE & F-WE \\
\hline Core self evaluation & $.430 * * *$ & $.391 * * *$ & $.398^{* * *}$ \\
Dukungan emosional & $.349 * * *$ & $.422^{* * *}$ & $.200^{*}$ \\
Dukungan instrumental & $.382^{* * *}$ & $.405^{* * *}$ & $.285^{* *}$ \\
\hline
\end{tabular}

$* \mathrm{p}<.05, * * \mathrm{p}<.01, * * * \mathrm{p}<.001$

Tabel 2

Hubungan Variabel Independen dengan Aspek Pengayaan Kerja Keluarga

\begin{tabular}{lcccccc}
\hline & W-FE D & W-FE A & W-FE C & F-WE D & F-WE A & F-WE E \\
\hline Core self-evaluation & $.320^{* * *}$ & $.373^{* * *}$ & $.398^{* * *}$ & $.423^{* * *}$ & $.271^{* * *}$ & $.414^{* * *}$ \\
Dukungan emosional & $.365^{* * *}$ & $.408^{* * *}$ & $.393^{* * *}$ & $.241^{* *}$ & .149 & .171 \\
Dukungan instrumental & $.348^{* * *}$ & $.387 * * *$ & $.384 * * *$ & $.309 * * *$ & $.195 *$ & $.295^{* *}$ \\
\hline
\end{tabular}

$* \mathrm{p}<.05, * * \mathrm{p}<.01, * * * \mathrm{p}<.001$

Tabel 3

Regresi Variabel Independen terhadap Pengayaan Kerja Keluarga

\begin{tabular}{lccc}
\hline & Total W-FE & W-FE & F-WE \\
\hline Core self-evaluation & $.373^{* * *}$ & $.334 * * *$ & $.350 * * *$ \\
Dukungan emosional & .138 & $.320^{* * *}$ & .045 \\
Dukungan instrumental & .211 & .093 & .166 \\
$\mathrm{R}^{2}$ & .287 & .303 & .195 \\
\hline
\end{tabular}

Tabel 4

Regresi Variabel Independen terhadap Aspek Pengayaan Kerja Keluarga

\begin{tabular}{lcccccc}
\hline & W-FE D & W-FE A & W-FE C & F-WE D & F-WE A & F-WE E \\
\hline Core self-evaluation & $.270^{* * *}$ & $.319^{* * * *}$ & $.333^{* * *}$ & $.376^{* * * *}$ & $.242^{* * *}$ & $.361^{* * * *}$ \\
Dukungan emosional & $.276^{* * *}$ & $.316^{* *}$ & $.291^{* *}$ & .098 & .056 & -.027 \\
Dukungan instrumental & .084 & .082 & .093 & .145 & .095 & .224 \\
$\mathrm{R}^{2}$ & .216 & .280 & .279 & .227 & .093 & .211 \\
\hline
\end{tabular}

Baral dan Bhargava (2011) menjelaskan bahwa core self-evaluation dapat mengarahkan individu untuk mencoba hal baru dan berusaha menyelesaikan tugas yang menantang sehingga individu memperoleh keterampilan dan perspektif yang baru. Keterampilan dan perspektif yang baru tidak hanya dapat berdampak terhadap domain pekerjaan melainkan juga dapat membantu individu dalam meningkatkan kualitas pada domain keluarga (Baral \& Bhargava, 2011; Moazami-Goodarzi dkk., 2015).

Friede dan Ryan (2005) menjelaskan bahwa core self-evaluation yang positif, akan mengarahkan individu untuk memilih dan menerapkan strategi yang lebih efektif untuk mengatasi tuntutan peran dan memanfaatkan kesempatan untuk berkembang dalam berbagai peran. Dengan demikian, individu yang memiliki core selfevaluation positif akan menganggap bahwa peran pada kerja dan keluarga bukanlah hal yang membebani, bahkan individu mampu mengelola tuntutan pada pekerjaan serta keluarga dengan baik sehingga mampu menurunkan konflik kerja-keluarga dan meningkatkan pengayaan kerja-keluarga (Hennessy, 2007; Selvarajan dkk., 2016; Westring \& Ryan, 2010).

Adanya peran dukungan atasan dalam memprediksi munculnya pengayaan kerja keluarga tidak terlepas dari teori Conservation of Resources (Hobfoll, 2001). Individu akan memanfaatkan sumber daya yang tersedia dari lingkungan untuk membantu mengembangkan dan mendapatkan lebih banyak sumber daya yang lain. Keterlibatan individu pada 
pekerjaan memungkinkan mendapatkan dukungan dari atasan yang dapat digunakan untuk mengembangkan kehidupan individu dalam menyeimbangkan dan mengintegrasikan peran dalam pekerjaan dan keluarga (Beham dkk., 2011). Dukungan yang diterima dari atasan dapat memperluas sumber daya psikologis, seperti kepercayaan diri yang berperan dalam meningkatkan kepuasan dan kesejahteraan individu baik pada pekerjaan maupun keluarga secara timbal balik (Baral \& Bhargava, 2011; Luo, 2011).

Temuan penelitian ini menunjukkan bahwa hanya dukungan emosional yang dapat memprediksi munculnya pengayaan kerja keluarga. Hal ini disebabkan aspek emosional menjadi faktor penting dalam kehidupan kerja dan keluarga (MacDermid dkk., 2002). Pengayaan kerja keluarga dapat terjadi melalui jalur afektif yaitu ketika individu merasakan emosi dan suasana hati pada satu peran dapat berdampak terhadap peran yang lain (Hanson dkk., 2006). Secara lebih lanjut, Greenhaus dan Powell (2006) menjelaskan bahwa jalur afektif dalam pengayaan kerja keluarga, dapat terbentuk ketika sumber daya yang diperoleh pada satu peran dapat menghasilkan emosi positif yang secara tidak langsung memengaruhi kinerja pada peran yang lain.

Dukungan yang diberikan oleh atasan secara emosional mengindikasikan adanya kepedulian dan empati yang ditunjukkan oleh atasan terhadap karyawan. Kepedulian dan empati tersebut tidak hanya mengenai dunia kerja tetapi juga mengenai tantangan dalam mengelola pekerjaan dan keluarga. Selain itu, atasan juga dapat mempertegas bahwa tanggung jawab karyawan terhadap keluarga, tidak akan tertahan pada pekerjaan karena atasan memiliki kuasa sebagai pengambil kebijakan di organisasi (Winfield \& Rushing, 2005). Dukungan emosional yang diberikan oleh atasan dapat meningkatkan kepercayaan diri dan mencegah terjadinya ketegangan ketika menjalani peran pekerjaan dan tuntutan keluarga (Baral \& Bhargava, 2011). Bahkan, dukungan emosional yang diberikan oleh atasan dapat menjadi energi positif dan menambah keyakinan karyawan dalam meningkatkan kualitas, baik pada domain pekerjaan maupun keluarga (Fung dkk., 2015).

\section{Simpulan}

Simpulan dari penelitian ini adalah ditemukan adanya hubungan core self evaluation dan dukungan atasan dengan pengayaan kerja keluarga. Pentingnya penilaian positif terhadap sumber daya yang dimiliki dapat menjadi modal psikologis individu dalam meningkatkan kualitas kehidupan kerja dan keluarga. Selain itu, interaksi positif antara karyawan dengan atasan dapat menjadi sumber daya yang bermanfaat dalam mengelola tantangan kehidupan kerja dan keluarga sehingga tercapainya pengayaan kerja keluarga.

\section{Daftar Pustaka}

Akram, H., Malik, N. I., Nadeem, M., \& Atta, M. (2014). Work-family enrichment as predictors of work outcomes among teachers. Pakistan Journal of Commerce \& Social Sciences, 8(3), 733-743.

Antani, A., \& Ayman, R. (2003). Gender, social support and the experience of work-family conflict. Paper presented at European Academy of Management, Milan, Italy.

Artiawati, A. (2012). Konflik kerjakeluarga pada jurnalis di Jawa dan Bali (Model konflik kerja-keluarga dengan ideologi peran gender, beban peran berlebih, dukungan sosial, dan kepribadian sebagai anteseden; rasa bersalah dan kesejahteraan psikologis sebagai konsekuensi) (Disertasi tidak diterbitkan). Universitas Padjadjaran.

Astutik, N. P., \& Artiawati, A. (2017). Hubungan antara keyakinan diri mengelola konflik kerja keluarga 
dengan dukungan atasan, dukungan keluarga dengan pengayaan kerjakeluarga. Journal of Psychological Science and Profession, 1(3), 1-7. https://doi.org/10.24198/jpsp.v1i3.149 68

Baral, R., \& Bhargava, S. (2011). Predictors of work- family enrichment: Moderating effect of core self- evaluations. Journal of Indian Business Research, 3(4), 220-243. https://doi.org/10.1108/175541911111 80573

Beham, B., Drobnič, S., \& Präg, P. (2011). Work demands and resources and the work-family interface: Testing a salience model on German service sector employees. Journal of Vocational Behavior, 78(1), 110-122. https://doi.org/10.1016/j.jvb.2010.07.0 08

Boyar, S. L., \& Mosley, D. C. (2007). The relationship between core selfevaluations and work and family satisfaction: The mediating role of work-family conflict and facilitation. Journal of Vocational Behavior, 71(2), 265-281. https://doi.org/10.1016/j.jvb.2007.06.0 01

Carlson, D. S., Grzywacz, J. G., \& Zivnuska, S. (2009). Is work-family balance more than conflict and enrichment? Human Relations, 62(10), 1459-1486.

https://doi.org/10.1177/001872670933 6500

Carlson, D. S., Kacmar, K. M., Wayne, J. H., \& Grzywacz, J. G. (2006). Measuring the positive side of the work-family interface: Development and validation of a work-family enrichment scale. Journal of Vocational Behavior, 68(1), 131-164. https://doi.org/10.1016/j.jvb.2005.02.0 02

Friede, A., \& Ryan, A. M. (2005). The importance of the individual: How self-evaluations influence the work- family interface. Dalam E. E. Kossek \& S. J. Lambert (Eds.), LEA's organization and management series. Work and life integration: Organizational, cultural, and individual perspectives (pp. 193-209). Lawrence Erlbaum Associates Publishers.

Fung, N. S., Ahmad, A., \& Omar, Z. (2015). Work-family enrichment: Its mediating role in the relationships between workplace support factors and teachers job satisfaction. American Journal of Applied Sciences, 12(4), 242-253. https://doi.org/ 10.3844/ajassp.2015.242.253

Greenhaus, J. H., \& Powell, G. N. (2006). When work and family are allies: A theory of work-family enrichment. Academy of Management Review, 31(1), 72-92. https://doi.org/10.5465/amr.2006.1937 9625

Hanson, G. C., Hammer, L. B., \& Colton, C. L. (2006). Development and validation of a multidimensional scale of perceived work-family positive spillover. Journal of Occupational Health Psychology, 11(3), 249-265. https://doi.org/10.1037/10768998.11.3.249

Hennessy, K. D. (2007). Work-family balance: An Exploration of conflict and enrichment for women in a traditional occupation (Dissertation unpublished). Faculty of the Graduate School of the University of Maryland.

Hobfoll, S. E. (2001). The influence of culture, community, and the nested-self in the stress process: Advancing conservation of resources theory. Applied Psychology, 50(3), 337-421. https://doi.org/10.1111/14640597.00062

Hunter, E. M., Perry, S. J., Carlson, D. S., \& Smith, S. A. (2010). Linking team resources to work-family enrichment and satisfaction. Journal of Vocational Behavior, $77(2)$, 304-312. 
https://doi.org/10.1016/j.jvb.2010.05.0 09

Jaga, A., \& Bagraim, J. (2011). The relationship between work-family enrichment and work-family satisfaction outcomes. South African Journal of Psychology, 41(1), 52-62. https://doi.org/10.1177/008124631104 100106

Jawa Pos. (2017, November 30). Kesetaraan gender di dunia industri, jumlah pekerja perempuan naik. JawaPos.com.

https://www.jawapos.com/ekonomi/30/11/ 2017/kesetaraan-gender-di-dunia-industrijumlah-pekerja-perempuan-naik/

Judge, T. A., Bono, J. E., Erez, A., \& Locke, E. A. (2005). Core selfevaluations and job and life satisfaction: The role of selfconcordance and goal attainment. Journal of Applied Psychology, 90(2), 257-268. https://doi.org/10.1037/00219010.90.2.257

Judge, T. A., Erez, A., Bono, J. E., \& Thoresen, C. J. (2003). The core selfevaluations scale: Development of a measure. Personnel Psychology, 56(2), 303-331.

https://doi.org/10.1111/j.17446570.2003.tb00152.x

Judge, T. A., Van Vianen, A. E. M., \& De Pater, I. E. (2004). Emotional stability, core self-evaluations, and job outcomes: A review of the evidence and an agenda for future research. Human Performance, 17(3), 325-346. https://doi.org/10.1207/s15327043hup1 7034

Koekemoer, E., Strasheim, A., \& Cross, R. (2017). The influence of simultaneous interference and enrichment in workfamily interaction on work-related outcomes. South African Journal of Psychology, 47(3), 330-343. https://doi.org/10.1177/008124631668 2631

Kossek, E. E., Pichler, S., Bodner, T., \& Hammer, L. (2011). Workplace social support and work-family conflict: A meta analysis clarifying the influence of general and work-family specific supervisor and organizational support. Personnel Psychology, 64(2), 289-313. https://doi.org/10.1111/j.17446570.2011.01211.x

Luo, L. (2011). A Chinese longitudinal study on work/ family enrichment. Career Development International, 16(4), 385-400. https://doi.org/10.1108/136204311111 58797

MacDermid, S. M., Seery, B. L., \& Weiss, H. M. (2002). An emotional examination of the work-family interface. Dalam R. Lord, R. Klimoski, \& R. Kanfer (Eds.), Emotions in the workplace (pp. 402-427). Jossey-Bass.

Marais, E., De Klerk, M., Nel, J. A., \& De Beer, L. (2014). The antecedents and outcomes of work-family enrichment amongst female workers. SA Journal of Industrial Psychology, 40(1). https://doi.org/10.4102/sajip.v40i1.118 6

McNall, L. A., Nicklin, J. M., \& Masuda, A. D. (2010). A meta-analytic review of the consequences associated with work-family enrichment. Journal of Business and Psychology, 25(3), 381396. https://doi.org/10.1007/s10869009-9141-1

Moazami-Goodarzi, A., Nurmi, J. E., Mauno, S., \& Rantanen, J. (2015). Cross-lagged relations between workfamily enrichment, vigor at work, and core self-evaluations: A three-wave study. Journal of Business and Psychology, 30(3), 473-482. https://doi.org/10.1007/s10869-0149376-3

Molino, M., Ghislieri, C., \& Cortese, C. G. (2013). When work enriches family- life: The mediational role of professional development opportunities. Journal of Workplace Learning, 25(2), 98-113. https://doi.org/10.1108/136656213112 
99780

Selvarajan, T. T. (Rajan), Singh, B., \& Cloninger, P. A. (2016). Role of personality and affect on the social support and work family conflict relationship. Journal of Vocational Behavior, 94, 39-56. https://doi.org/10.1016/j.jvb.2016.02.0 04

Shein, J., \& Chen, C. P. (2011). Work family enrichment a research of positive transfer. Senses Publishers.

Siu, O. L., Bakker, A. B., Brough, P., Lu, C., Wang, H., Kalliath, T., ... Timms, C. (2015). A three-wave study of antecedents of work-family enrichment: The roles of social resources and affect. Stress and Health, 31(4), 306-314. https://doi.org/10.1002/smi.2556

Voydanoff, P. (2004). The effects of work demands and resources on work-tofamily conflict and facilitation. Journal of Marriage and Family, 66(2), 398412. https://doi.org/10.1111/j.17413737.2004.00028.x
Voydanoff, P. (2005). Toward a conceptualization of perceived workfamily fit and balance: A demands and resources approach. Journal of Marriage and Family, 67(4), 822-836. https://doi.org/10.1111/j.17413737.2005.00178.x

Westring, A. F., \& Ryan, A. M. (2010). Personality and inter-role conflict and enrichment: Investigating the mediating role of support. Human Relations, 63(12), 1815-1834. https://doi.org/10.1177/001872671037 1236

Winfield, I., \& Rushing, B. (2005). Bridging the border between work and family: The effects of supervisoremployee similarity. Sociological Inquiry, 75(1), 55-80. https://doi.org/10.1111/j.1475682X.2005.00112.x 
Psympathic, Jurnal Ilmiah Psikologi Juni 2020, Vol. 7, No. 1, Hal. : 19-30 